\title{
HENRY NEWELL MARTIN (1848-1893). A PIONEER PHYSIOLOGIST
}

\author{
by
}

\author{
C. S. BREATHNACH
}

STARLING's very first paper in the series which culminated in the enunciation of the Law of the Heart begins (Knowlton and Starling, 1912): 'The isolation of the heart after the method of Newell Martin possessed certain advantages over other methods. The heart is supplied with blood properly oxygenated by the lungs and it pumps the blood against a measured resistance, and thus can be made to work under conditions closely approximating to normal ...'

Henry Newell Martin was born in Newry, Co. Down, on 1 July 1848, both his parents being Irish, his father coming from the South and his mother from the North of Ireland. His father was a schoolmaster who had forsaken the Congregational ministry, and Henry, the eldest of twelve children, was educated chiefly at home. When not yet sixteen years he matriculated at the University of London and began his studies at the medical school of University College, at the same time, under financial dictate, becoming apprentice to Dr. McDonagh in the nearby Hampstead Road, London (Foster, 1896). Here he had the good fortune to meet, and have his talent recognized by, Michael Foster, then Sharpey's assistant:

\begin{abstract}
These lectures [by M. Foster] on [experimental] physiology were absolutely voluntary, and only the better students were willing to give up the time needed to get a more thorough grasp of physiology. Well, I appointed a time to see the few who wished to spend some time in this new study, this study of luxury, and there came to me a boy, nothing more than a boy, who said: 'I am very sorry, sir, I would like to take your course if I could, but you see my parents are not very well off, and I get my board and lodging by living with a doctor close by . . . I have, in return for my board, to dispense all the doctor's medicines, and that dispensing takes me from two to five; now your lectures begin at four. I cannot come for the first hour; I will work hard and will try to make up the lost time.' I said 'certainly, certainly.' So he came in, came in regularly late. He came in regularly at five o'clock, and he worked with such purpose that in the examination which I had at the end of the course I awarded him the prize. Well, his name was Henry Newell Martin, and I was so much struck with him that I asked him to assist me in my course, and he became my demonstrator ....
\end{abstract}

In October 1870 Martin went up on a scholarship to Christ's College, Cambridge; at the same time Foster moved up as Praelector of Physiology at Trinity College, and not surprisingly was glad to have his old pupil continue as his assistant in introducing a course in elementary biology. Subsequently he acted as assistant to T. H. Huxley (the originator of the course) at the Royal College of Science in the same programme, and the two published Practical Biology in 1876.

In 1873 he gained first place in the Natural Science Tripos at Cambridge and with his B.Sc. won the Scholarship in Zoology. He proceeded to the D.Sc., being the first to take that degree in Physiology; not neglecting to qualify in medicine (M.B.) in London. While engaged in these academic pursuits, sweetened by the necessity to earn some money by teaching, Martin found time to carry the standard of biology 


\section{S. Breathnach}

into the undergraduate arena, for he became President of the Union and Captain of the Volunteers, no mean achievement for a mere naturalist. In 1874 he was made Fellow of his College and just as he was about to blossom forth in the cradle of English physiology, the New World beckoned. Huxley and Foster recommended him to Dr. Gilman of Baltimore, Maryland, and in 1876 he was invited to become the first occupant of the chair of biology which had been established in the Johns Hopkins University.

To Martin, assisted by William K. Brooks, the teacher of Ross Harrison whose pre-eminence in experimental embryology was still undimmed at his death in 1959, fell the task of launching biological science in the infant Johns Hopkins University; its famous medical school was not founded for another seventeen years. Martin, in fact, took part in the preliminary organization but he and his colleagues realized that his health was failing fast in 1893 so that his pupil W. H. Howell replaced him as professor of physiology in May and the medical school opened its ample doors in October 1893. A memorial tablet at Hopkins commemorates 'his brilliant work as investigator, teacher, author' by which 'he advanced knowledge and exerted a wide and enduring influence.' Martin's sincerity and loyalty to truth, his kindly tact and helpfulness, made him a cherished friend among his pupils and one of them, Henry Sewall, later professor of physiology in Denver, Colorado, recalled their first meeting (Sewall, 1911):

... my spirits were lightened when I saw a young man, he was then twenty-eight and looked younger, who treated me at once something like a companion. He was scarcely of medium height, of slight but well developed frame. His head was rather small, the eyes blue and wide open, nose thin and fine, complexion fair and mustache blond. His dress was always strikingly neat without being foppish ... . Martin accepted me as his assistant in the biological laboratory at a stipend of 250 dollars for the first six months. Not for many months did I suspect that this was at first a private and not a University appointment ... His invariable kindliness where he had bestowed confidence withstood every strain of daily intercourse . . . .

In 1879 Martin married Hetty Cary, a celebrated beauty and woman of great fascination, the widow of General Pegram, a Confederate officer, and 'after his marriage he invited pupils to a weekly informal conference at his home where with his talented wife he supplemented the impersonal relations of the laboratory with the ties of social intercourse'. The same joyous personality, the cultured mind in a mere scientist, especially in a biologist, made him welcome in the medical circles of Baltimore and indeed among the social elite in the New World generally 'for he made weekly visits to New York to talk biology in an exclusive women's club for a considerable period'. Martin had no family and in 1892 his wife (who was considerably older than he) died. His old friend and teacher wrote with not a little feeling of his closing years (Foster, 1896):

... Even before his wife's death his health had begun to give way, and after that he became so increasingly unfitted for his duties, which his own previous exertions had raised to a very great importance, that in 1893 he resigned his post. After his resignation he returned to England, for he had never become an American Citizen, and was looking forward to being able, with improved health, to labour in physiological investigations, either at his old University or elsewhere in England. But it was not to be. Though he seemed at times to be improving, he had more than one severe attack of illness and never regained sufficient strength to set really to work. During 


\section{Henry Newell Martin (1848-1893). A Pioneer Physiologist}

the past summer he visibly failed, and while he was striving to recover his strength by a stay in the quiet dales of Yorkshire, a sudden haemorrhage carried him off, on 27 October, at Burleyin-Wharfedale, Yorkshire.

According to Sewall (1911) his teacher was fond of saying 'We know a good deal about the skeletal muscle because we can isolate it and of the frog's heart for the same reason'. The frog's heart had been forced to yield up many of its secrets: not so the mammalian heart which succumed rapidly so soon as experimental interference was attempted:

... I very well remember one morning, I think it was in the fall of 1880 , Martin said to me, in effect, 'I could not sleep last night and the thought came to me that the problem of isolating the Mammalian heart might be solved by getting a return circulation through the coronary vessels.' The idea seemed reasonable and at the close of the day's work we anaesthetised a dog, prepared him for artificial respiration and then Professor Martin opened the chest and ligatured one by one the venae cavae and the aorta in such a way as to leave sufficient amount of blood in the heart itself. The heart continued to beat in a normal manner, the circuit made by the blood being from the right side, through the lungs to the left side and back through the coronary vessels in the heart wall to the right auricle again. Thus heart and lungs were completely isolated from the rest of the body and could be studied unaffected by the interference of factors foreign to itself. Martin grasped the full significance of his discovery and elaborated with infinite patience the practical details involved in submitting the isolated organ to experimental conditions . . . .

Martin had been working with one of his pupils W. T. Sedgwick, who had come from Yale and would later shine in the Massachussetts Institute of Technology, on the blood pressure in the coronary arteries (a subject which he would take up again) and it occurred to him that the essential difference between cold- and warm-blooded animals probably lay in the coronary circulation. Over the next three years his students, notably William Henry Howell (his successor at Hopkins in 1893) and Frank Donaldson, helped in developing the heart-lung preparation. 'The study of the physiology of the mammalian heart [was] made possible to an extent never before attainable', for the heart was 'physiologically isolated from everything [including the nervous system] but the lungs.' The direct action of any drug upon the heart (the only one so examined, by Martin and Lewis T. Stevens, 1883, was alcohol), the effect of temperature, of arterial pressure, of venous pressure, of metabolites, could individually be examined; and all were. It seemed also practicable 'to unite a given organ, say kidney or liver, with the heart and keep it alive for study', but there is no record that such an attempt was made.

Within very wide limits, it was early shown (1882) that changes in arterial pressure have no influence whatever upon the pulse rate of the isolated heart of the dog. In the Croonian Lecture in 1883 all the evidence was neatly collected and showed that the isolated mammalian heart, just like the frog's, 'beat quicker when warmer blood was supplied to it, and slower when it gets cooler blood'. An important observation which was made possible by the Germanic thoroughness of the investigators is worth quoting in full, for it shows once again that 'fortune favours the prepared mind' in Pasteur's happy phrase: ' . . . It is not the temperature of the blood in its cavities which influences the rate of beat of the dog's heart, but the temperature of the blood sent to its capillaries. In other words, temperature changes do not influence the pulse 


\section{S. Breathnach}

rate by stimulating afferent nerves in the endocardium which then act upon cardiomotor ganglia, but they act directly upon the muscle fibres or nerve cells of that organ ...' (Gaskell had not yet settled the matter of neurogenic or myogenic origin of the heart beat.)

Mr. W. H. Howell and Mr. Frank Donaldson (1882) in Martin's laboratory showed 'that variations in venous pressure greatly affected the work done by the heart', without having an effect on the pulse rate. The two young protégés (1884), who used the professor's method and thanked him for his encouragement when 'success seemed doubtful', and for his personal assistance on occasion, studied in detail the influence of variations in venous pressure, arterial pressure and pulse rate on left ventricular output and thus, by calculation knowing also arterial pressure, the work of the heart. 'Variations in arterial pressure within normal limits have practically no effect whatever on the quantity of blood sent out from the ventricle at each systole' but 'the work done by the left ventricle at each systole increases with the venous pressure, but not proportionally, up to the point of maximum work.' Their results in six experiments making variations in venous pressure, if summarized graphically, show a pattern that is clearly a prologue of the Starling curves, and lest anyone should ask why young Howell and Donaldson did not convert their tabulated results into diagrams it need only be mentioned that it was not until they reached their third paper (Starling and Patterson, 1914) that Starling and his friends did so.

In their fourth paper, Patterson, Piper and Starling (1914) defined Starling's law for the first time-in terms that are no longer familiar-'the mechanical energy set free on passage from the resting to the contracted state depends on the . . . length of the muscle fibres.' It had become clear from their work on the regulation of the heart beat that 'the output of the heart is a function of its filling, the energy of its contraction depends on the state of the dilatation of the heart's cavities.' For good measure this paper explained the mechanism of failure and defined tone: 'the energy set free per unit length of muscle fibre at each contraction of the heart.' In the Linacre Lecture on the Law of the Heart, delivered in St. John's College, Cambridge, in May 1915, and published in 1918, Starling made the following generalization: "within physiological limits the larger the volume of the heart, the greater are the energy of its contraction and the amount of chemical changes at each contraction.' He showed conclusively that length of fibre and not the tension it was under was the essential factor determining the strength of contraction of the cardiac muscle and concluded that 'the law of the heart is thus the same as the law of muscular tissue generally, that the energy of contraction however measured is a function of the length of the muscle fibre.' Unfortunately he permitted himself to luxuriate in speculative theory and attributed the increased cardiac output in response to the increased venous return in exercise to lengthening of the muscle fibres as a consequence of dilation, albeit temporary dilation.

Chapman and Mitchell (1965) are rightly at pains to show that the Linacre Lecture was not Starling's final work on heart function but is more correctly but a prelude to his Royal Army Medical Corp address 'on the circulatory changes associated with exercise' (1919). Therein is the little known paragraph that puts his detractors to flight: 


\section{Henry Newell Martin (1848-1893). A Pioneer Physiologist}

... as Haldane has so often insisted no organ of the body works by itself or for itself, when we speak of heart failure we must think of this organ, not as an isolated hollow mass of muscle, but as one which is brought into relation with all parts of the body and with the changes impressed on the body from without through the central nervous system. In analysing the factors involved in these complex adaptations we shall do well to start with the powers and properties of the heart itself; but must always remember that the extraordinary powers with which the heart muscle is endowed represent but the central fortress of the system, and under normal conditions are protected, and to a large extent, prevented from coming into play by the activities of the defending positions and outposts provided by the central nervous system and its servants. It is only when these other defences fail that the heart is called upon to display these reactions which are at once brought to light in our study of the isolated organ. But no understanding of the circulatory reaction of the body is possible unless we start first with the fundamental properties of the heart muscle itself, and then find how these are modified, protected, and controlled under the influence of the mechanisms-nervous, chemical, and mechanical-which under normal conditions play upon the heart and blood vessels.

From a description of the heart-lung preparation and its use in the derivation of the law of the heart, Starling went on to discuss the cardiac reflexes and to give an excellent résumé of the physiology of adrenaline. That he had, since the Linacre Lecture, advanced as far as the most modern 'circulators' is made abundantly clear in a later passage:

... In studying the reactions of the isolated heart, dilatation of the heart seems to be the only mechanism of the unfailing response of this organ to any increase in the demands made upon it. But the effect of throwing this organ into the circle of control by the central nervous system is that it is kept in rest or activity in an equable condition, and the dilatation, which was so marked a condition of its reaction when isolated, is reduced to such small dimensions in the heart reined in and controlled by the cardiac centres, and helped by the correlated changes in other organs, that it becomes imperceptible in the intact animal, and is not revealed, for instance, by any radiographic study of the heart during exercise. (Italics added.)

Experimental observations, electro-technological as well as radiographic, confirming this view, so succinctly stated in 1919, gradually accumulated and were taken as evidence against the general applicability of Starling's law (Liljestrand et al., 1928; Warren et al., 1945; Stead et al., 1946; Stead and Warren, 1947; Hamilton, 1955; Rushmer, 1955, 1959). Construction and study of Starling curves, however, have accomplished the rehabilitation of the Law (McMichael, 1952; Sarnoff and Berglund, 1954; Sarnoff et al., 1960; Chapman et al., 1960; Chapman, 1960; Braunwald et al., 1961; Gleason and Braunwald, 1962; Harrison et al., 1963; Glick et al., 1964; Robinson et al., 1966). The Starling mechanism is obscured by autonomic activity but can be demonstrated in abnormal circumstances, so that the latest statement of the case runs: 'In spontaneous exercise, the normal heart utilizes a combination of mechanisms to increase its output, which include an increase in heart rate, the FrankStarling mechanism, and an increase in myocardial contractility.' (Bevegord and Shepherd, 1967). If pedants insist, as nowadays they are inclined to do, on the dual eponym in the Frank-Starling mechanism, why not say its study is facilitated by the Martin-Starling preparation?

Martin used his preparation to study the direct effect of ethyl alcohol on the dog's heart (with L. T. Stevens, 1883) and the supposed suction pump action of the heart (with F. Donaldson, 1887). With W. T. Sedgwick (1882) he showed that the mouths of the coronaries are not blocked by the semilunar valves during ventricular systole, 


\section{S. Breathnach}

as Brucke supposed; and, with the help of Mr. Lingle, in a study of the vasomotor nerves to the heart (1891) he realized that the vagus was not a coronary dilator. But these were of small moment beside another paper. In studying the temperature limits of the vitality of the mammalian heart with E. D. Applegarth (1890) Martin realized that his major problem was 'to keep the cardiac vessels well supplied with blood whether the heart beat feebly or strongly' and that its solution lay in 'connecting the aortic stump of the isolated heart with a Mariotte flask filled with blood and kept at a constant level above the organ ... [so that] a constant pressure would be maintained in the coronary arteries, quite independent of the force of the heart's beat.' Martin's description of his new departure (Figure 2) runs:

... All branches of the aortic arch except the coronaries were of course closed. The blood supplied to the aortic stump (from the Mariotte flask through $p$ ) could thus escape only through $q$ into the funnell shown in the plate, or through the circuit $q$ indicated by dotted lines, and consisting of the coronary vessels ... The side tube $q$ is designed to get rid of the difficulty of insufficient aeration of the blood; were it not present, the only flow from the aorta would be through the coronary system, and the flow would be so slow that it would be impossible to renew the blood in the cannula fast enough to keep it from using up its own oxygen and becoming very venous, and unfitted to keep the heart at work. But by a free outflow through $q$, the blood in the cannula is quickly changed, and, moreover, so rapid a bubbling of air through the supplying Mariotte flask occurred, that the flask takes the place of a lung and supplies arterial blood (flask 'closed above' except for a bubbling tube $m$ ).

Admittedly this was not an isolated heart for the pulmonary circulation continued through intact lungs, but there is in the closing sentence an unequivocal statement that the double aortic cannula and Mariotte flask were so arranged as to act as an artificial oxygenator. In describing his method of aortic cannulation in the isolated heart five years later, Langendroff (1895) does not mention this 1890 paper but adds an appendix (Zusatze) to make clear that his technique owes nothing to Martin's 1881 heart-lung preparation, although he cannot have been entirely unaware of it after 1887 when young Donaldson (1887) published a paper in Du Bois-Reymond's Archiv, on the subject. Starling acknowledged his debt to his predecessor but, although there can be no question of priority, a doubt must remain as to how much Martin contributed to the development of Langendorff's isolated perfused heart. Certainly the two great methods of investigating independently the mammalian heart were first planned and used by the Newry man.

Before tackling and solving the problem the mammalian heart presented to physiological analysis, Martin had already gainfully applied the experimental method to the study of respiratory movement and its control, and the results of the work carried out with his students in the early years at Hopkins were published in three papers which appeared in 1879-his third year in the chair. What is most simply called an apneustic effect was demonstrated by stimulation of the optic lobes of the frog (Martin) and of the lower midbrain of the rabbit (with W. D. Brooker). In the first paper he concluded that these effects are mediated through neurones in the medulla oblongata where: 'we must assume . . . that we have really two distinct centres, one for inspiration and one (normally less easily discharging) for expiration, and that each has its own stimulus and generates its own nervous impulse which can travel only to its own set of muscles, quite independently of the resistance opposed 


\section{Henry Newell Martin (1848-1893). A Pioneer Physiologist}

to discharge from the other centre'.

Clearly the writer was thinking in terms of inspiratory and expiratory muscles and may be said to have been 'insensibly led on' to an examination of the intercostals. From a theoretical analysis of the geometric relationships of the ribs and intercostal muscles Hamberger (1748) put forward the view that the external intercostals and the intercartilaginous portion of the internal intercostal muscles are inspiratory and the interosseous internal intercostals are expiratory. In 1873 Onimus, from experiments on a guillotined criminal, showed by means of electricity that the external intercostals raise the ribs and are inspiratory, while the internal ones depress them and are expiratory. In spite of this confirmation of Hamberger's theory Volkman (1876-77) was prepared to spend nearly forty pages discussing 'zur theorie der intercostalmuskelen'. It was left to Newell Martin and E. M. Hartwell 'to try the experiment':

... It seemed to us, however, that, by isolating an internal intercostal and then observing whether it contracted simultaneously or alternately with the diaphragm, its function could be settled; since, from the general co-ordination of muscular contraction in the respiratory movements, there can be no doubt that muscles excited from the respiratory centre and contracting during respiration simultaneously with the diaphragm, are inspiratory muscles: and that those contracting when it relaxes, are expiratory.

They found that all the internal muscles were expiratory but nearly twenty years later Masoin and Du Bois-Reymond (1896), using the method devised by Martin, confirmed Hamberger in finding that the intercartilaginous muscles do contract synchronously with the diaphragm.

Like his celebrated townsman, Barcroft, Martin was gifted with the happy phrase, the fecund simile: 'bringing blood abundantly to the cells will not make them drink;' 'For the difference between the fully developed human body and the collection of amoeboid cells which represent it at the morula stage, is essentially the same as that between a number of wandering savages and a civilised nation.' As early as 1888 he was railing against the information explosion, then as now largely caused 'by sciolists' indulging in 'the pleasant amusement of making a so-called research' publishing 'trash, the reading of which is pure weariness of spirit'. Conscious that wealth is not health he warned that 'science cannot for any long period advance safely in chains, even if these chains be golden'.

In introducing his first course in the foundling Johns Hopkins University on 23 October 1876, Newell Martin handed on to a new world of biological sciences (his sole competitor and colleague being Henry Pickering Bowditch, professor of physiology at Harvard) 'the golden heresy of truth':

... This is a university: and the object of a university, I take it, is directly to promote the liberality of thought and culture, and only indirectly to concern itself with the practical advancement of material welfare ... in subsidiary schools .... One of the great glories of [study of] all the physical sciences [lies] in the promotion of large and liberal ideas, and in the gratification of that longing to 'know', which is the noblest characteristic of the human intellect .... .

... All that is needed for good and valuable work ... is undaunted perseverance and absolute truthfulness; a perseverance unabated by failure after failure, and a truthfulness incapable of the least perversion ... or of the least reluctance to acknowledge an error once it has been found to have been made .... 


\section{S. Breathnach}

... theories are necessary to guide and systematise a scientist's work, and to lead to its prosecution in new directions, but they must be servants and not masters . . . . (Italics added.)

... to make a great leader and master in science ... far rarer powers are needed ... all the rest of us can do when we meet such men is to give them a free course and ungrudging help .... ... real scientific work ... requires wide knowledge and extended views, and is more valuable the broader the foundation on which it has been built up . . . we shall give no quarter to the indolent or ignorant ... no good work is likely to be done ... in physiological investigation ... by devoting to it an hour or two at irregular intervals ....

... Let us leave a record which, if it perchance contain the history of no great feat in the memory of which our successors will glory, will at least contain not one jot or tittle of which they can be ashamed.

Small wonder that in 1900 Sir Michael Foster, founder of Britain's outstanding school of physiology in Cambridge, the home of Langley, Gaskell, Barcroft, Adrian, Matthews and others, boasted in Denver, Colorado, 'So if I have done nothing more, at all events I sent Henry Newell Martin to America'.

\section{ACKNOWLEDGEMENT}

This essay grew out of a copy of Newell Martin's Physiological Papers which was given to me by my teacher, Dr. D. H. Barron, into whose debt I have fallen irredeemably.

\section{REFERENCES}

BEVEgARD, B. S., and SHEPHERD, J. T., 'Regulation of the circulation during exercise in man', Physiol. Rev., 1967, 47, 178-213.

Braunwald, E., Frahm, C. J. and Ross, J., JR., 'Studies on Starling's law of the heart. V. Left ventricular function in Man', J. clin. Invest., 1961, 40, 1882-90.

Chapman, C. B., 'On the nature of cardiac control', Ann. int. Med., 1960, 53, 1272-80.

Chapman, C. B., BaKer, O., and Mitchell, J. H., 'Left ventricular function at rest and during exercise', J. clin. Invest., 1959, 38, 1202-13.

Chapman, C. B., Fisher, J. N., and Sproule, B. J., 'Behaviour of stroke volume at rest and during exercise in human beings', $J$. clin. Invest., 1960, 39, 1208-13.

Chapman, C. B., and Mrtchell, J. H., Starling on the Heart, London, Dawson, 1965, p. 176.

Donaldson, F., JR., Arch. Anat. Physiol. wiss. Med., ed. C. D. Reichert and E. Du BoisReymond, 1887, p. 587.

Foster, M., 'Henry Newell Martin', Proc. $R$. Soc., 1897, 60, xx-xxiii.

Foster, M., Colorado med. J., 1900, cited by Sewall.

Gleason, W. L., and Braunwald, E., 'Studies on Starling's Law of the heart. V. Relationships between left ventricular end-diastolic volume and stroke volume in man with observations on the mechanism of pulsus alternans', Circulation, 1962, 25, 841-48.

Glick, G., Sonnenblick, E. H., Williams, J. F., JR., and BraunWald, E., 'Effects of exercise performed at constant heart rate on myocardial force-velocity relations and ventricular dimensions in intact unanaesthetised man' (abstr.), Circulation, 1964, 30, suppl. 3: III-85.

HAMBERGER, G. E., De Respirationis mechanismo, 1748, cited by Volkmann.

Hamilton, W. F., 'Role of the Starling concept in regulation of the normal circulation', Physiol. Rev., 1955, 35, 161-68.

Harrison, D. C., Goldblatt, A., Braunwald, E., Glick, G., and Mason, D. J., 'Studies on cardiac dimensions in intact unanaesthetized man', Circulation Res., 1963, 13, 448-67.

Howell, W. H., and Donaldson, F., JR., 'Experiments on the heart of a dog with reference to the maximum volume of blood sent out by the left ventricle in a single beat, and the influence of variations in venous pressure, arterial pressure, and the pulse-rate upon the work done by the heart', Phil. Trans. R. Soc., 1884, 175, 139-60. 


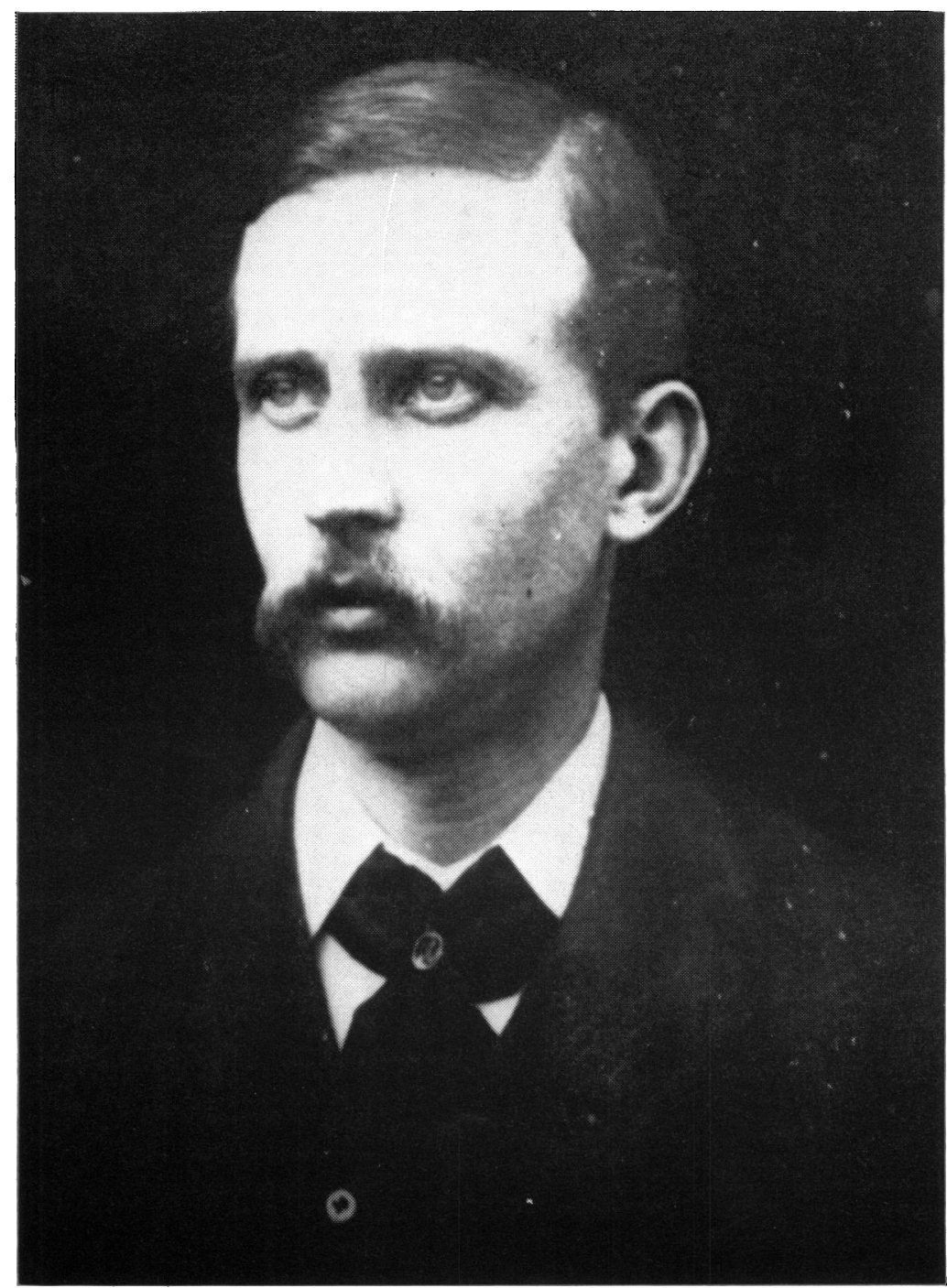

Figure 1.

Henry Newell Martin (1848-1893). 


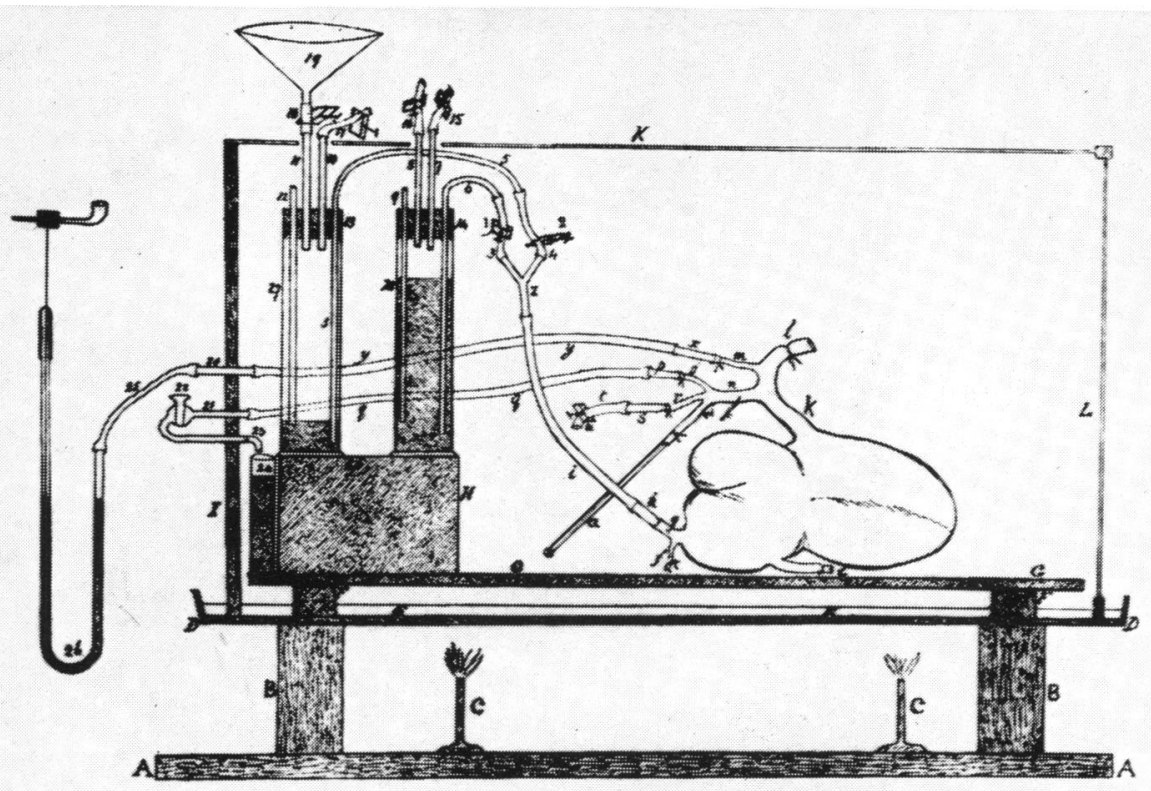

Figure 2.

Martin's arrangement of the first mammalian heart-lung preparation.

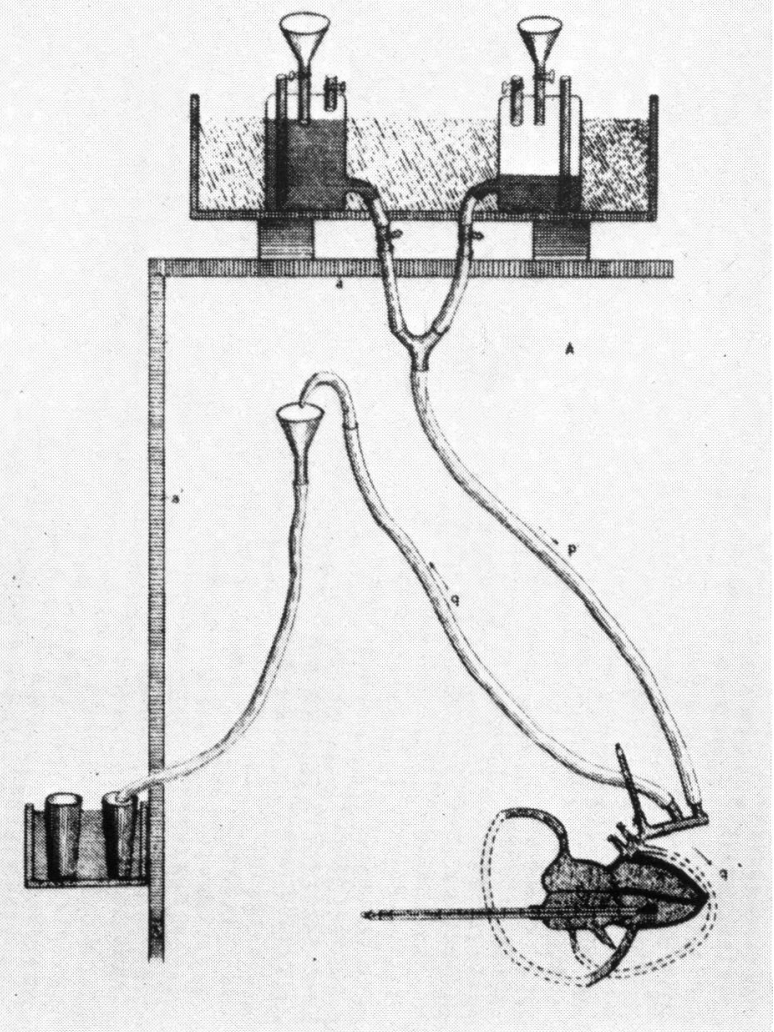

Figure 3.

Perfusion of the coronary vessels at constant pressure with blood oxygenated artificially. 


\section{Henry Newell Martin (1848-1893). A Pioneer Physiologist}

Knowlton, F. P., and Starling, E. H., 'The influence of variations in temperature and blood pressure on the performance of the isolated mammalian heart', J. Physiol., $1912,44,206-19$.

LANGENDORFF, O., 'Untersuchungen am überlebenden Saugethierherzen', Pflügers Arch. ges. Physiol., 1895, 61, 291-332.

LiIJESTRAND, G., Lysholm, E., and NyLin, G., 'The immediate effects of muscular work on the stroke and heart volume in man', Skand. Arch. Physiol., 1938, 80, 265-82.

McMicharl, J., 'Dynamics of heart failure', Brit. med. J., 1952, 2, 525-29.

Martin, H. N., Physiological Papers, Baltimore, Johns Hopkins Press, 1895.

Masoin, and Du Bois-ReYmond, E. H., Arch. Anat. Physiol. wiss. Med., 1896, p. 85, cited by E. A. Schäfer, Textbook of Physiology, vol. II, 1898, p. 279.

Onimus, Gaz. Med. Chir., 24 January 1873, cited by StiRLnNG, E. (Extracts), J. Anat. Physiol., $1874,8,203$.

Patterson, S. W., Piper, H., and Starling, E. H., 'The regulation of the heart beat', J. Physiol., 1914, 48, 465-513.

Patterson, S. W., and Starling, E. H., 'On the mechanical factors which determine the output of the ventricles', J. Physiol., 1914, 48, 357-79.

Robinson, B. F., Epstein, S. E., Kohler, R. L., and Braunwald, E., 'Circulatory effects of acute expansion of blood volume: Studies during maximal exercise and at rest', Circulation Res., 1966, 19, 26-32.

Rushmer, R. F., 'Applicability of Starling's law of the heart to intact unanaesthetized animals', Physiol. Rev., 1955, 35, 138-42.

RUSHMer, R. F., 'Constancy of stroke volume in ventricular responses to exertion', Am. J. Physiol., 1959, 196, 745-50.

SARNOFF, S. J., and BerGlund, E., 'Ventricular function. I. Starling's law of the heart studied by means of simultaneous right and left ventricular curves in the dog', Circulation, 1954, 9, 706-18.

SARnoff, S. J., Brockman, S. K., Gilmore, J. P., Linden, R. J., and Mrtchell, J. H., 'Regulation of ventricular contraction: influence of cardiac sympathetic and vagal nerve stimulation on atrial and ventricular dynamics', Circulation Res., 1960, 8, 1108-22.

Sewall, H., 'Henry Newell Martin, Professor of Biology in Johns Hopkins University, 1876-1893', Johns Hopkins Hosp. Bull., 1911, 22, 327-33.

StaRling, E. H., The Linacre Lecture on the Law of the Heart, London, Longmans, Green, 1918.

Staring, E. H., 'On the circulatory changes associated with exercise', $J$. $R$. Army med. Corps., 1920, 34, 258-72.

Stead, E. A., JR., Brannon, E. S., Merrill, A. J., and Warren, J. V., 'Concentrated human albumin in the treatment of shock', Arch. int. Med., 1946, 77, 564-75.

STEAD, E. A., JR., and WARREN, J. V., 'Cardiac output in man. An analysis of the mechanisms varying the cardiac output based on recent clinical studies', Arc. int. Med., 1947, $80,237-48$.

Volkmann, A. W., 'Zur theorie der intercostalmuskelen', Z. Anat. EntwGesch., 1876-77, 2, 159-197.

Warren, J. V., Brannon, E. S., Stead, E. A., JR., and Mrrrill, A. J., 'The effect of venesection and pooling of blood in the extremities on the atrial pressure and cardiac output in normal subjects with observations on acute circulatory collapse in three instances', J. clin. Invest., 1945, 24, 337-44. 